\title{
THE IMPORTANCE OF THE MIDDLE EAST IN RUSSIAN FOREIGN POLICY'
}

\author{
Seyed Javad Emam Jomehzadeh ${ }^{2}$ \\ Sanaz Rostamjabri ${ }^{3}$ \\ Mahnaz Goodarzi ${ }^{4}$
}

\section{Introduction}

The importance of international issues, especially in the tense region Middle East, as well as testing the power of foreign powers for more influence in the region, led to several research in this field. Since the Middle East region has always been full of conflicts, any power can invade the region. Therefore, it is difficult for any nation to be able to gain the trust of the countries in the region (Shokoohi 20II).

As Russia was facing many problems after the collapse of Soviet Union, Putin first tried to promote a revival of domestic politics with a pragmatic approach in order to enter the international arena. So, after solving domestic problems it could assert his international power. In this regard, regional politics has been very important, and the Middle East region had been attracting the interest of great powers for some time, including Russia and the United States.

The Russian government under Putin's leadership is trying to set

I This article is taken from the dissertation of Sanaz Rostam Jabri, PhD in International Relations, entitled "Analysis of Russia's foreign policy towards the Middle East during the second term of Vladimir Putin (20I6-20I2)" under the guidance of Dr. Seyed Javad Imam Jomehzadeh.

2 Associate Professor, Department of Political Science and International Relations, Isfahan University, Isfahan, Iran.

3 PhD student, Department of Political Science and International Relations, Khorasgan Branch, Islamic Azad University (Khorasgan), Isfahan, Iran.

$4 \mathrm{PhD}$ Candidate from the Department of Political Science and International Relations, Khorasgan Branch, at Islamic Azad University (Khorasgan), Isfahan, Iran. 
apart its policy in this region from the United States, especially in his second term. Putin's priorities are building balanced and stable relations with all governments and players in the Middle East region. According to Kremlin officials, the only way to protect its southern borders as well as the Central Asia region and the Caucasus from developments in Middle East such as terrorism, religious fundamentalism, weapons of mass destruction, etc. is to use various mechanisms and instruments close to the countries in the region (Kiani 2009).

\section{Russia's Motives for Its Projection in the Middle East}

Russia's presence in the Middle East is based on several important factors. The first factor is maintaining the status quo in the region; the second factor for Russia's presence in the Middle East is the war on terror and preventing its spread to Russia; and finally, it should be noted that as the U.S. presence and involvement in the Middle East decreases, Russia seeks to expand its influence in the region. This provides a good opportunity for Russia as an active player to exercise its power beyond its borders when threatened (Khalabenikov 2016).

One of Russia's main concerns is the significant hydrocarbon energy resources that exist in the Middle East and oil and gas exports are also very important for Russia. At the same time, the export of military weapons to this region is also very important for Russia, and it can be said that it is a market with a very big perspective for Russia. In addition, it should be noted that the Middle East is very important in the fight against terrorism. As Russian President Vladimir Putin has said, it is better for Russia to fight terrorism in more remote areas than in its own country. But in general, Russia's expectations of the Middle East include several important aspects of national security and a global role.

In this sense, Russia aims, as a first priority, to push back the jihadists, as at least 2,500 Russian citizens and hundreds from other CIS countries are ready to join ISIS in Syria and Iraq. The return of these fighters is in itself a real threat, as in Western Europe. Since Moscow is the second largest city in the Muslim world in Europe, with a population of about 2.5 million, the Kremlin takes the threat of extremism seriously.

The second issue is the strategic rivalry with the United States. This is a traditional rivalry between Moscow and Washington. The third priority relates to the Middle East region relevance in energy production since global oil prices are critical to the Russian economy. This is evidenced by cartel 
agreements with OPEC major producers - or efforts to resolve existing conflicts, particularly the competition between Saudi Arabia and Iran.

The fourth factor that shows the importance of the Middle East is linked to its relevance as an attractive consumer market of goods and weapons. The war in Syria has shown that Russia is capable of producing, deploying, and supporting advanced weapons systems ranging from medium-caliber cruise missiles to SU -35 fighter jets to S-400 missile defense systems. Finally, the Syrian civil war has shown that Moscow's loyalty towards its allies is stronger than Washington's (Cohen 20I7).

\section{The Main Reasons for Russia's Attention to the Middle East}

During Vladimir Putin 's first term, Russia emphasized the need for full cooperation with the West, especially with the United States, so the Middle East region did not play an important role in Russian foreign policy during those years (Kolaei 2007). However, under Putin's second term, Russia's attention focused on the Middle East grew (Khalabnikov 2016).

Russia pursues a number of interests in the Middle East, including economic interests. Being aware of Russia's economic weakness, Putin is trying to save Russia's foreign policy and engage in serious economic diplomacy (Kolai and Nouri 20II). This can be clearly seen in Putin's first and second visits the Middle East region in 2005 and 2007. Putin was joined by the heads of two armaments companies MIG and Rosoburn Sport during his visits to Saudi Arabia, Egypt, Qatar and Jordan. These actions show that Russia pays special attention to relations with developing economies of the Middle East region, in order to generate foreign revenues. Also, more can be mentioned. In fact, Russia not only wants to expand the market for arms sales in the Middle East, but also seeks to play a role in the energy sector of these countries (Kiani 2007).

In terms of security, the Middle East is of particular importance to Russian foreign policy. After the collapse of the Soviet Union, new countries had emerged on the southern borders of Russia, in which about 20 million people are Muslims. What happened after the collapse of the Soviet Union in some Muslim parts of Russia, including Russia's wars with Chechnya, spread pessimism among Muslims, and Russia was declared an enemy of Islam. In fact, Russia fears the spread of religious extremism in the regions under its influence, which is why it tries to stabilize the region and maintain balanced relations with its the countries. Russia wants to establish peace and stability in the Middle East and therefore supports the elaboration of a roadmap in the 
Middle East, because in this way it can strengthen its position in the region (Mousavi 2006).

The Middle East is also politically important for Russia. In this context, attention should be paid to Russia's relations with the United States. Indeed, Russia's presence in the Middle East depends on the extent of U.S. presence in Russia's periphery and backyard. Indeed, U.S. proximity to some countries in Russia's south, including Georgia, strengthens Russia's relations with some countries in the Middle East, including Syria and Iran, and even with Palestinian groups like Hamas, to put the United States in a more sensitive position. Also, Russia tries to limit the country's influence in Central Asia, the Caucasus and the Middle East regions (Kiani 2007).

\section{Security Reasons}

The main driver of Russian foreign policy in the Middle East is security. Russia is aware that the security landscape in the Middle East is not clear due to the deepening of ethnic and sectarian divisions and the intensification of fundamentalism. This represents a serious concern. The religion of the majority of the population of Central Asia is Islam. In South Caucasus Azerbaijan is a Muslim country, and Georgia and Armenia have small Muslim populations. It is not far-fetched that the tensions in the Middle East increase anti- Russian Islamic tendencies abroad. A clear example of this are the problems faced by leaders of Central Asian governments during the Taliban rule in Afghanistan. In general, these leaders are pro-Russian, and therefore Islamic fundamentalism is a threat to Russia's interests. Moreover, Moscow is concerned about the political tendencies that will emerge among the Muslims of this country in the future (Deilami Moezzi 20II).

Russia's other security concern stems from Russia's position as a world power. Moscow tries to resort to military means as little as possible to achieve its goals in Europe. In such an environment, the reality that Europe needs Russian gas is a good way to counter policies from this region and other neighboring areas that may threaten Russia's security and interests. When Ukraine and Georgia announced their intention to join NATO, Russia responded by restricting gas supplies to these countries. Meanwhile, Old Europe, especially Germany, urged Kiev and Tbilisi to pay more attention to Russia's concerns. Therefore, gas is a strategic and security tool for Russia. Moscow is trying to maintain Europe's dependence on Russian gas. In recent years, Europe has turned to the Middle East to diversify its gas supply, a policy that concerns Russia (Deilami Moezzi 20II). 
Russia has entered the Middle East gas program to counter efforts, that may threaten its power in this energy sector. Although this move is economic in nature, it actually has significant strategic and security implications. Moscow, as mentioned earlier, will try not to jeopardize Russian access to European markets and will balance the Middle East. Moreover, in the context of becoming a superpower, Russia sees power in the energy sector as an inevitable priority, if it participates in gas programs and projects in the Middle East and in the Persian Gulf (Hosseini 2006).

\section{Political Reasons (Restoration of Foreign Policy)}

Russia's agenda in the Middle East region also has political aims and approaches. One of them is to restore Russia's tarnished image among the Muslims of the world. New Russia (known as the greatest heir to the Soviet Empire) has taken actions that have offended Muslims around the world. The most important of these was the brutal repression of the Chechen independence movement. Although Russia failed to control the crisis in I994 during Yeltsin's presidency, Putin pursued harsh and even inhumane policies in 1999 that severely suppressed the separatist tendencies of the Chechen Muslim people (Friedman 2006).

During Putin's second term, Russia opened a new chapter in its relations with the Middle East. In addition to Turkey, Iran and Syria, the Kremlin was eager to expand its relations with allies that were also closer to the United States. Increasing relations with Qatar, Saudi Arabia, the United Arab Emirates, Jordan and Egypt should be seen in this context. This increases Moscow's presence on the Middle East and has a positive impact on the Kremlin's bargaining power vis-à-vis the White House. U.S. involvement in Iraq and Afghanistan, curbing terrorism and fundamentalism in the Middle East, South, and Central Asia, Iran's nuclear program, the Arab-Israeli peace process, and the control of weapons of mass destruction are, according to Russian politicians, is a sensitive issue. The document U.S. Foreign Policy Energies also was analyzed in order to make sense of this scenario and to create a suitable ground for Russia to play its role (Friedman 2006).

Russia's political efforts to establish relations with the Middle East are within the framework of Russia's security objectives. In particular, the development of relations with countries previously mentioned such as Saudi Arabia, Qatar and United Arab Emirates, and to some extent Egypt, should be seen in the context of Moscow's efforts to contain Salafism in the South and North Caucasus. Although there are more foreign supporters of Salafist 
groups in the Caucasus than in the Middle East, it seems that Russia will limit its relations with them. However, Russia has chosen a different path and is trying to increase its diplomatic clout in order to contain and control the Salafist extremists through these governments (Deilami Moezzi 20II).

\section{Economic Reasons}

The Middle East is important to any growing economy. Due to its significant dollars reserves obtained from oil, the countries of this region get to enjoy the luxuries and advanced goods of the world. Apart from Israel, Turkey and to some extent Iran, most of the other countries meet their needs from abroad. Moreover, these countries are among the largest buyers of arms in the world. These countries have also recently expressed a desire to take advantage of the nuclear industry, especially in the area of power generation, and there are suitable opportunities for Russia in the above areas (Bremer and Charap 2007).

The positive economic features of the Putin era confirm his focus on the economy. Analysts say that Putin was the first politician to explicitly attribute Russia's economic weakness to its passive behavior in the I990s, and this understanding underscores his importance. According to Putin, without convergence with the structures of the international economy, it is impossible to achieve the desired level of economic and social development. Otherwise, the development process will be slow and difficult (Bremer and Charap 2007).

\section{Russia's Interests at Middle East}

\section{Economic Interests}

In 20I7, Russian economy had suffered heavy losses due to the falling of international oil prices. The Crimean monopoly, sanctions and other structural problems put pressure on the state budget. Under these circumstances, reliable sources of revenue were sought, which changed Russia's perception of trade opportunities in the Middle East. As a result, the prioritization of economic gains led to a significant increase in Russian activity in the Middle East and in the volume of trade between Russia and the region between 2012 and 20I7. Given the challenges facing the Russian economy, cooperation with Middle Eastern countries has become more important for several reasons. First, trade relations have been on the rise since the early 
2000 s.

The fact that the Russian trade balance in the Middle East is in Russia's favor makes the region an attractive market for Russian goods military equipment, machinery, oil and gas, petrochemicals, metallurgy, and agricultural products. In this sense, trade with the region is useful for implementing the government's economic diversification strategy. Moreover, despite the relatively small share of oil and gas (compared to petrochemicals) in Russian exports to the Middle East, Moscow sees the potential of the Middle East as a buyer for its natural gas. Russia is also promoting its space industry in the Middle East with products such as the GLONASS satellite navigation system. From 20I2-I7, cooperation with Middle Eastern countries in the field of nuclear energy is another focus of Russian trade (Kajanov 2018).

One of the main reasons for Russia's cooperation with countries in the region is to offset the negative impact of Western sanctions against Russia. Thus, the countries of Middle Eastern have gained importance as agricultural exporters, whose production can help replace European products under antiRussian sanctions (Kajanov 20I8).

\section{Energy Interests}

Russia has economic and trade interests in the energy sector on the Middle East. This energy includes nuclear energy and oil and gas. Russian state-owned companies such as Gazprom and Rosatom (State Economic Energy Corporation) pursue significant energy interests in key consumer markets, oil and gas fields, and nuclear energy infrastructure customers in countries such as Iran, Iraq, Turkey, Kurdistan, and Eastern Mediterranean. Slowly Rosatom has expanded its operations in the Middle East in recent years by building reactors in Iran, Egypt, Jordan and Turkey. It also opened a regional office in Dubai in hopes of further linkages with the UAE and Saudi Arabia to increase its nuclear energy capacity. Fluctuations in global energy markets and Russia's increasing dependence on oil revenues as a result of declining economic power due to Western sanctions have increased pressure on Moscow to reach Middle East energy markets (Saden et al. 20I7).

\section{Arms Trade Interests}

The Middle East arms market is not new to Russia. The Soviet Union exported arms to Algeria, Egypt, Syria, Iraq, Iran, Libya, Sudan and Yemen. But the collapse of the Soviet Union reduced Russia's arms exports. Russia's 
armaments industry was damaged by the Boris Yeltsin governmental policies, and in addition, important Russian factories on the territory of the new republics made themselves independent, which led to the loss of ports such as Odessa and Ilyichevsk, which were important weapons depots (Kayanov 2016).

At least since 1999, Russia has been one of the largest arms exporters in the world. In recent years, the Middle East and the North Africa (MENA) region have become the second most important Russian arms market after Asia. From 2000 to 2016 , the Middle East and the North Africa region accounted for about one-fifth of Russian arms exports. In 2009, for example, Moscow sold about $\$ 9$ billion worth of weapons to the region; in 2016, the figure was up to \$2I.4 billion (Bershchevsky 20I7). Traditional customers presented a slight decline, but Russia tried to keep its revenues with these other countries.

Between 20II and 20I5, the volume of arms deals signed between Moscow and the Middle East increased significantly, including Russia's return to the Egyptian-Iraqi arms market, which had recently been affected by the United States. Russia signed a \$3.5 billion deal with Cairo in 20I4 under which Moscow will sell MIG -29M/M2 fighter jets, Mi-35M attack helicopters, an S-300VM missile complex and a coastal defense system to Egypt. Also in 20I5, Irkut agreed to supply I2 Su-30K fighter jets to Egypt (Kajanov 20I6).

Some countries prefer Russian weapons to American ones, mostly for obvious reasons, and the U.S. does not sell weapons to many Russian customers for various reasons. They are inexpensive and generally often comparable to American systems. In some areas Moscow's systems are extremely poor in quality and performance, but in others they are a close competitor. For example, Moscow was very good at building anti-aircraft missiles, such as the S-300 and S-400 systems, based on lessons learned from the Kosovo air war. Currently, the American F-35 fighter can be attacked by the $\mathrm{S}-400$ (although there is no way to prove this until they are in direct combat).

However, Moscow is developing the next generation S-500, which full capabilities are not yet known. Russia's current generation of aircraft and ballistic missile defenses are comparable to U.S. defense technology. Some Russian missiles are still like American missiles, some even work better. Moreover, the US Foreign Military Sales System (FMS) is very slow, bureaucratic and cumbersome, while Moscow, once the contract is signed, takes less time to deliver the equipment to buyers. (Breshchevsky 20I7). 


\section{Strategic Interests}

Russia's strategy in the Middle East is to align with other actors in the region. However, Russia pursues this strategy not because it wants to play the main role in the Middle East, but because it wants to have as much influence as possible in the region. This allows Moscow to cooperate with the United States in the Middle East. If the United States rejects Russia's offer to cooperate, Russia will at least worsen the situation for the United States in the region. Russia's top priority is Ukraine, and it has perceived U.S. interference as a threat in recent years. Moscow hopes that as long as the United States focuses on the Middle East, it will be less inclined to intervene in Ukraine (Snyder 20I7).

Russia's strategy in the region includes several cases. First, Russia is using its continued pragmatism in the region and talking to each regional power in the Middle East about its intentions. Given the complexity of the Middle East realities, a balancing strategy between all the major players in the region was not initially envisaged. But Russia was able to convince its political partners to focus on discussing areas where Russia and the Middle East can work together rather than trying to drag Russia into regional disputes (Kajanov 20I8).

Second, Russia is flexible in its regional dialogue but very determined to defend its major interests. For example, it exercises its veto power in the United Nations to support the Assad regime or to support laws that do not formally comply with UN. Russia is also concerned about any change in the Middle East borders and is strictly against any dialogue with radical Islamists (Kajanov 20I8).

Third, Russia is working hard to make its role comparable to that of the United States in the region. In this sense, the strong memory of the Soviet presence during the Cold War that still exists among policymakers and nations in the Middle East is useful, although Russia cannot compete politically and economically with the United States. Russia exploits the shortcomings of Western policy in the Middle East. For example, the U.S. reluctance to protect Mubarak, compared to Moscow's support for Assad, has encouraged regional powers to view Russia as a reliable partner (Kajanov 20I8).

Fourth, Russia formally avoids ideological dialogue with the Middle East. In talks with countries and political groups in the region, Russia tries to focus on differences and contradictions. In most cases, Russia is still very practical (Kajanov 20I8).

Finally, Russia's economic efforts are focused on areas of market 
advantage: Nuclear energy, oil and gas, petrochemicals, space, weapons, and grain. At the same time, Russian trade on the Middle East is based on the claim "Chinese prices with European quality". Low prices and reliability are the main reasons why Middle Eastern countries are interested in Russian nuclear technology. In March 20I5, Russia and Jordan signed a \$Io billion agreement that will allow Rostov to build and operate two 2,000-megawatt nuclear reactors. During Putin's visit to Egypt in February 2015, Rostom signed a contract to build Egypt's first nuclear power plant (Kajanov 20I8).

\section{Final Remarks}

The Middle East has long been known for its ethno-religious divisions, oil, fundamentalism, and Arab-Israeli conflict. It has been great, but there has never been a full security without war and conflict, and this has led to foreign powers invading the region and intervening on many policies and making decisions.

One of these foreign powers that has always tried to project itself in the Middle East was Russia. After the fall of the Russian monarchy and the rise of the anti-imperialist Soviet regime, Moscow did not stop its presence and adventures in the region. The adventures that occupied the northern part of Iran and the establishment of sham regimes like the Republic of Mahabad or the arming of pan-Arab governments, especially the Baathist regimes in Iraq and Egypt, can be mentioned. With the fall of the Soviet Union and the onset of widespread unrest within Russia, the Kremlin had long forgotten about the Middle East until faltering oil revenues and weak U.S. policy provided a favorable environment for the Russian bear to return to the Middle East; a return that Iran is also largely pursuing in the current situation to ensure its national interests and national security (Mahmoudian 2016).

As the countries of the Middle East and their governments have always been politically weak, the influence of foreign powers had led to more and more unrest. They have tried to turn the countries of the region against each other, so we have seen an increase in conflicts. Among the important issues we can mention are the Arab-Israeli conflict, the problems between the countries of the region and the important and attractive issue of oil. The superpowers were content with their influence, but with the collapse of the Soviet Union (I99I), the Middle East increasingly came under the influence of the US to dominate the region alone. Therefore, with the formation of a new Russia and efforts to improve the internal situation, Russia's foreign policy turned back to the Middle East and countries that were against the US 
presence found more hope in Russia.

Another reason for Russia's presence in the Middle East is to try to maintain the status quo rather than change it, because a secure Middle East region that can solve Russia's security, economic, and political problems is far better than any other situation. So, it is consistent with the aggressive realist assumption that governments are trying to maintain the status quo.

Another point that has been observed in recent years is Russia's strong presence in the conflicts on the Middle East, especially in Syria, because Moscow, in order to prove itself as an international power and restore its power, must necessarily have a strong presence in sensitive areas. On the Middle East, it could show Russia's influence and importance. Since powers always see the hypothetical enemy as a threat to themselves and Russia needs the United States as a long-time rival, aggressive thinking is always present in the security scene because it always has to fight for the rest.

Therefore, the article has shown that pragmatism as a primary policy and restoration of power played a key role at the beginning of Putin's presidency, but with the entry into the international arena and the attainment of hegemonic power, Moscow entered the realm of realism. The offensive explained well the role and presence of Russia in restoring its power in the Middle East, as international countries need a strong presence in key areas to maintain their power and security, and Russia is very aware of this. In this sense, the text has explained the role and importance of Russia's presence in the Middle East and the reasons behind it.

\section{REFERENCES}

Ariel, C. 20I7. "Russia's Return To The Middle East: America Beware." The Navigator from CGP, CENTER FOR GLOBAL POLICY. https://www. cgpolicy.org/articles/russias-return-to-the-middle-east

Baliev, A. 20I5. "Iyerusalim Pomozhet' [Jerusalem Will Help]". Rossiyskaya Gazeta, June o9, 20I5. Access on Jul I7, 20I6. http:// rg.ru/20I5/06/09/tovarooborot.html

Borshchevskaya, A. 20I7. "Can Trump Break Up the Russian-Iranian Alliance?”. The Tower, February, 20I7. http://www.thetower.org/ article/can-trump-break-up-the-russian-iranian-alliance/

Bremmer, I.; S. Charap. 2006. “The Siloviki in Putin's Russia: Who they are and What They Want". The Washington Quarterly 30(I): 83-92.

Deilami Moezzi, A. 20I0. "Russia's Foreign Policy in the Middle East in the First Decade of the 2Ist Century". Iras Bi-Quarterly, Fifth Year, (6): 
84-90.

Friedman, G. 2006. "The Middle East and Russia New Game”. World View, February I4, 2006. https://worldview.stratfor.com/article/middleeast-and-russias-new-game

Hosseini, H. 2006. "What is a crisis and how is it defined?". Security Quarterly, Fifth Year, No. I and 2: 4.

James, S.; Wasser, B.; Connable, B.; Grand-Clement, S. 20I7. "Russian Strategy in the Middle East: Expert Insights on a Timely Policy Issue". RAND Corporation. Available at: https:://sicurezzaterrorismosocieta. it\%2 Fwp-content\%2 Fuploads\%2 F2OI9\%2Fo6\%2 FSicTerSoc_9. pdf\&usg=AOvVaw346MKeMxPrbAS2mnRBmH2p

Khalabnikov, A. 20I6. "What is Russia looking for in the Middle East?". Tabnak News, June i9, 2016. http://www.tabnak.ir/fa/news/599152/. p4-I

Kiani, D. 2007. "Russia's policy in the Middle East: Axis and stimuli, Deputy Foreign Policy Research". CMESS.ir, December 23, 20II. https:// www.cmess.ir/Page/View/20II-I2-23/916

Kolaei, E. 2007. "Russia-Israel relations on Iran, Iranian diplomacy". DIPLOMACY.ir, January 2007. Available at: http://irdiplomacy.ir/ en/page/III27.p3I0-3I2

Kolaei, E.; Nouri, A. 20I0. "Putin's Pragmatism and Change in Russia's Foreign Policy Approaches”. Politics Quarterly, 40 (2): 222.

Kozhanov, N. 20I7. "Russia and OPEC: Will the Relations Last?". TRENDS, October 26, 20I7. Access on Dec. 25, 20I7. http://trendsinstitution. org/russia-and-opecwill-the-relation-last/

Mahmoudian, A. 20I6. "Russia, the Middle Eastand us". DIPLOMACY.ir, June, 20I6. Available at: http://www.irdiplomacy.ir/fa/page/ig66030/

Mousavi, S. 2006. "Russia and the Middle East under Putin". Defense Leadership Quarterly, Institute of Iran-Eurasia Studies (IRAS), Fourth Year, No. II. http://www.iras.ir/nslhtio2dna3i.ft2.html.oı8-ı6

Nikolay K. 20I6. "Arms Exports Add to Russia's Tools of Influence in Middle East". Chatham House: The Royal Institute Of International Affiars, July 20, 20I6. https://www.chathamhouse.org/expert/comment/ arms-exports-

Nikolay K. 2018. "Russian Policy Across theMiddle East Motivations and Methods". Chatam House: The Royal Institute Of International Affiars, February 2I, 20I8. https://www.chathamhouse.org/2018/02/ russian-policy-across-middle-east 
Shokoohi, S. 20II. "Russia's Transformational Foreign Policy in the Middle East During Medvedev's Presidency”. International Center for Peace Studies. Available at: http://peace-ipsc.org/fa

Snyder, Glenn H. 2002. "Mearsheimer's World offensive Realism and the Struggle for Security". International Security 27 (I): 34-50.

\begin{abstract}
The Soviet Union emerged as a superpower in the Cold War, and after the collapse of the Soviet Union in I99I, a new Russia was formed. To achieve the hegemony of power, Russia's security document was given priority. In the first term, Vladimir Putin focused on pragmatism and emphasized the power of domestic politics and the revival of the Russian economy. In his second term, Putin focused on the politics of realism to gain power on the international stage and return to what Moscow is interested in. In his second term, Putin pursued a political (power expansion), security (avoiding differences), and economic (strengthening Russia) view Middle East. Therefore, in this study, Russian foreign policy in the Middle East and its importance The question for this study is: what factors in Russian foreign policy made the Middle East region important for Russia? And the hypothesis for this question: Russia's concern about Islamic fundamentalism (security), economic and political reasons are among the most important factors in directing its foreign policy to the Middle East.
\end{abstract}

\title{
KEYWORDS
}

Soviet Union; Russia; Vladimir Putin; Foreign Policy; Middle East.

Received on March 28, 2021

Approved on April 20, 2021 